\title{
Montana State University Library Social Media Survey
}

Thank you for completing this brief survey. You rock!! These questions are designed for the MSU-Bozeman community. The survey was developed by MSU Librarians to help us better understand social media use and expectations.

* Required

1. How do you identify yourself within the MSU-Bozeman community? * Mark only one oval.

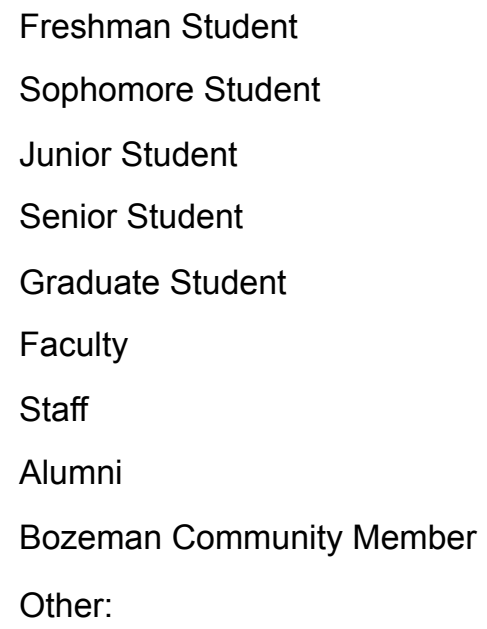

2. What is your major or discipline?

3. What city and state are you from?

for example, Bozeman, MT

\section{What is your gender?}


5. Which social media networks are you aware of?

Check all that apply.

$\square$ Facebook

$\square$ Twitter

Tumblr

$\square$ Instagram

$\square$ Pinterest

$\square$ Foursquare/Swarm

$\square$ Flickr

$\square$ YouTube

$\square$ Vine

$\square$ Snapchat

$\square$ Yik-Yak

$\square$ Blogs

$\square$ Other:

\section{What is your use of social media?}

Mark only one oval.

Heard of it

Visited in past month

Posted in past month

7. How many social media sites have you visited in the past month? Mark only one oval.
0
1
2
3
4
$5+$ 
8. Which social media sites have you visited in the past month?

Check all that apply.

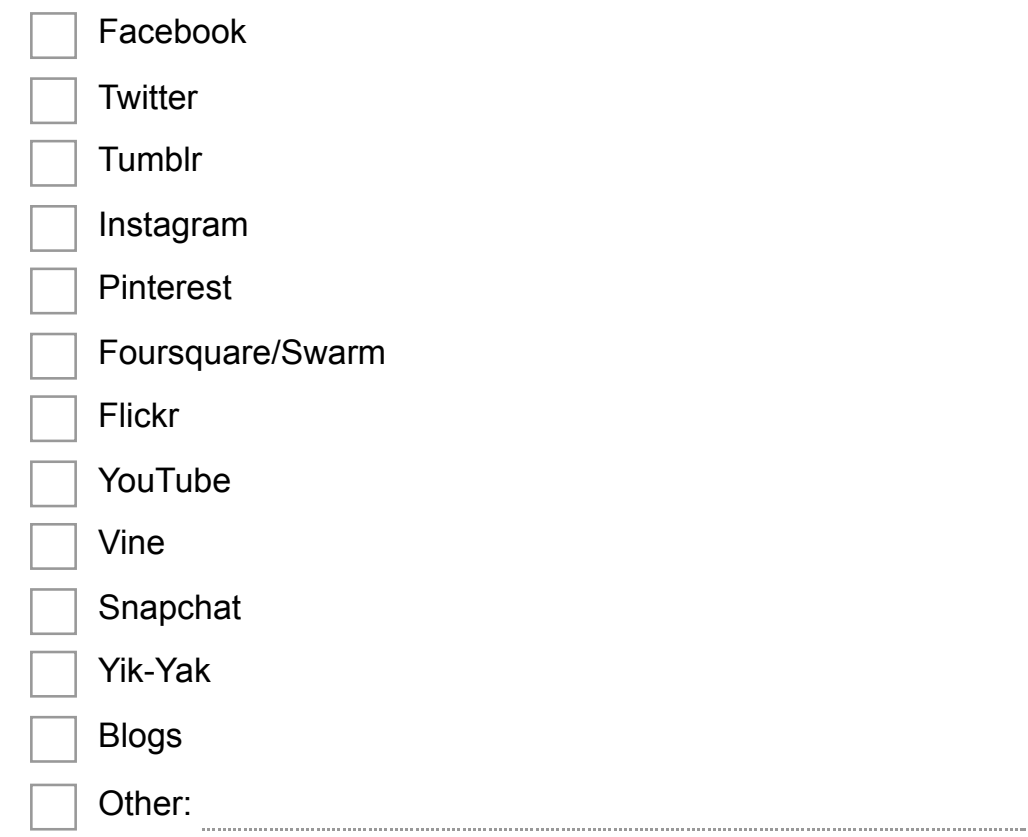

\section{How often do you use social media?}

Mark only one oval.
Never
Rarely
Monthly
Weekly
Daily

10. How often do you use the following social media sites?

Mark only one oval per row.

Facebook
Twitter
Yine
Yninaphir
Yik-Yak
Blogs


11. What is the value of each of these social media of networks to you? Mark only one oval per row.

Facebook
Twitter
Tumblr
Instagram
Pinterest
Foursquare/Swarm
Yickr
Vine
Yikaphat
Blogak

12. What is your opinion of social media?

Mark only one oval per row.

Social media takes up more time
than it is worth
Social media is a valuable way to
connect with others
You feel a social pressure to be
active on social media
You feel a possibility of missing
out if not active on social media

13. What are barriers to your use of social media?

Check all that apply.

$\square$ Privacy

Time

Confidence in the social network

$\square$ Unfamiliarity with the social network

Lack of reliable internet access

Lack of mobile connectivity

Other:

14. From where do you typically access social media?

Mark only one oval per row.

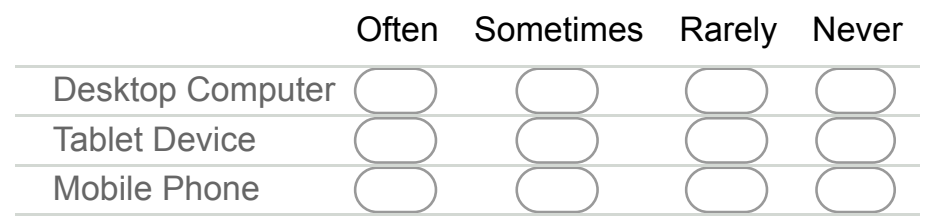


15. How often do you use social media to connect with the library?

Mark only one oval.

Never

Rarely

Monthly

Weekly

Daily

16. What is your opinion of the MSU Library and social media?

Mark only one oval per row.

Strongly agree Agree Neutral Disagree Strongly disagree

The Library should use social media to connect with students

You expect to see shareable

content from the Library

17. I expect to see the following types of content from the MSU Library

Mark only one oval per row.

Strongly agree Agree Neutral Disagree Strongly disagree

Historical photographs
Book-related posts
Events
About the Library and librarians
Workshops
Community posts about
Student interactions
Humor
Research materials

18. Which social media accounts would you like to use to connect with the MSU Library?

Check all that apply.

Facebook

Twitter

Tumblr

Instagram

Pinterest

Foursquare/Swarm

Flickr

YouTube

Snapchat

I Yik-Yak

B Blogs 
19. Which social media accounts have you used to connect with the MSU Library?

Check all that apply.

$\square$ Facebook

$\square$ Twitter

$\square$ Tumblr

$\square$ Instagram

$\square$ Pinterest

$\square$ Foursquare/Swarm

$\square$ Flickr

$\square$ YouTube

$\square$ Blogs

20. Optional: if you would like to speak with us more about social media, please leave your contact information.

Name (first, last):

21. Email

Powered by

Boogle Forms 